\title{
Immediate and Residual Haematotoxicity in Mice Exposed to Wastewater from a Cocoa Processing Industry
}

\author{
Okunola Adenrele Alabi
}

Department of Biology, Federal University of Technology, Akure, Ondo State, Nigeria.

Received $5^{\text {th }}$ July, 2021, Accepted $2^{\text {nd }}$ October, 2021

DOI: 10.2478/ast-2021-0006

*Corresponding author

Okunola Adenrele ALABI E-mail: alabiokunola@yahoo.com

Tel: $++234-8034416394$

\begin{abstract}
This study investigated the constituents and haematotoxic potential of wastewater collected from a cocoa processing industry in mice. The mice were intraperitoneally injected for 5 consecutive days with $0.3 \mathrm{~mL}$ of $1,5,10$, 25 and 50\% concentrations of the wastewater. Blood was collected from some mice on the last day of the injection to assess the immediate effect of the wastewater on selected haematological parameters while blood was collected from others 21 days after the last injection to assess its residual effect. Blood collected were analyzed using an Abacus Reflotron machine. Haematological parameters including packed cell volume (PCV), white blood cells (WBC), red blood cells (RBC), heamaglobin (HGB), lymphocytes, erythrocyte indices: Mean corpuscular heamaglobin count ( $\mathrm{MCHC})$, mean corpuscular heamablobin $(\mathrm{MCH})$, mean corpuscular volume $(\mathrm{MCV})$; leucocyte differential count: Neutrophils, Monocytes, Basophils and Eosinophils were analyzed. A significant decrease in basophils, $\mathrm{MCH}, \mathrm{MCHC}$, $\mathrm{HGB}$, and PCV; and a significant increase in neutrophils, monocytes, eosinophils, MCV, total WBC count, and lymphocytes were observed in mice exposed to the wastewater compared to the negative control after 5 days. A similar trend of the alterations of the heamatological parameters was observed in mice 21 days after exposure, even though the values were numerically lower than in the 5 days exposed mice. Results further showed the presence of $\mathrm{Zn}, \mathrm{Cd}, \mathrm{As}, \mathrm{Mg}, \mathrm{Ni}, \mathrm{Cu}, \mathrm{Fe}, \mathrm{Cr}, \mathrm{BOD}, \mathrm{COD}$, and EC at concentrations higher than allowable limit by standard organization. Cocoa industry wastewater is capable of inducing hematotoxicity, therefore, proper waste management should be followed in the disposal of such toxic waste.
\end{abstract}

Keywords: Cocoa Industry wastewater, haematotoxicity, blood parameters, physico-chemical analysis, heavy metals. 


\subsection{Introduction}

Population increase, industrialization, and urbanization are major contributors to waste pollution in most developed and developing nations. The wastes generated are in different forms including effluents, solid waste, and sludge. Most of these wastes (untreated or partially treated) are discharged indiscriminately directly or indirectly into aquatic bodies with the potential of rendering the water unwholesome and contaminated for human use. This is because most industrial wastewaters are complex mixtures of several organic and inorganic compounds with potential toxic effect (Bakare et al., 2013). Cocoa industry is an industry which requires freshwater in large volume at various steps of manufacturing cocoa and therefore also produced a large volume of wastewater. This wastewater contain different chemicals some of which are hazardous at different concentrations. Chemical composition of Cocoa industry wastewater include dyes, amines, salts, bleach, acid/alkali and having high concentration of total dissolved solids (TDS), Electrical Conductivity (EC), biochemical oxygen demand (BOD), chemical oxygen demand (COD), and heavy metals such as cadmium (Cd), chromium (Cr), lead $(\mathrm{Pb})$, copper ( $\mathrm{Cu}$ ), iron (Fe), etc (Akinnusotu and Arawande, 2016). These chemicals have the potential to bioaccumulate and biomagnified within the food chain to a threshold level with deleterious effect on human. It is therefore, imperative to evaluate the potential toxicity of these wastewaters so as to generate useful information for the environmental authorities in formulating laws for proper wastewater management.

It has been documented that there are adverse effects of exposure to different chemical substances in industrial wastewater on the haematology of different organisms. This might be due to the interaction of the wastewater constituents with blood forming tissues and blood components. Blood is a specialized body fluids which is responsible for the transportation of hormones, oxygen, nutrients, and other metabolites to different cells of the body while removing metabolic waste products from the cells to elimination sites (Rahman and Siddiqui, 2006). As the most important body fluid, blood regulates various vital body functions such as circulation, temperature balance, osmotic, excretion, and respiration. Analysis of blood/haematological parameters is one of the rapid ways of detecting exposure to stress or toxicants in an organism and it is an important tool in the assessment of diverse health conditions (Hymavathi and Rao, 2000). Indeed, data from the literature have shown that alterations in haematological parameters in organisms exposed to different toxicants are valuable indicators of stress, infections and diseases in such organisms (Rahman and Siddiqui, 2006; Yakubu et al., 2007). Therefore, analysis of haematological parameters can be used in the assessment of the potential toxicity of a pollutant or contaminant on the blood constituents of an organism. Thus, this present study aimed at determining the immediate and residual effects of exposure to cocoa industry wastewater on the haematological parameters of Swiss albino mice.

\subsection{Experimental}

\section{Sample collection}

The wastewater from a Cocoa processing industry in Akure South Local Government (Longitude 5016'E and Latitude $7^{0} 28^{\prime} \mathrm{N}$ ), Ondo State,
Nigeria, was collected prior to disposal into a sterile 10-litres plastic container from the main point where the wastewater is discharged from the industry to the environment. The wastewater was kept at $4^{\circ} \mathrm{C}$ throughout the period of this study.

\section{Physico-chemical properties and heavy metal analysis}

Standard physico-chemical properties were analyzed in the wastewater including TDS, COD, acidity, alkalinity, chlorides, BOD, ammonia, nitrates, and phosphates according to the method described by APHA (2005). Standard analytical methods (APHA, 2005; USEPA, 2009) were also used for the analysis of selected metals: $\mathrm{Cd}, \mathrm{Ni}, \mathrm{Cr}, \mathrm{As}$, $\mathrm{Pb}, \mathrm{Cu}, \mathrm{Fe}, \mathrm{Mn}$, and $\mathrm{Zn}$, in the wastewater sample. Briefly, concentrated $\mathrm{HNO}_{3}$ was used to digest $100 \mathrm{~mL}$ of the wastewater by heating until the volume is reduced to $3-5 \mathrm{~mL}$. Then, $0.1 \mathrm{~N} \mathrm{HNO}_{3}$ was added to increase the volume to $10 \mathrm{~mL}$ before metal concentrations were estimated using Atomic Absorption Spectrophotometer (Perkin Eelmer E. Analyst, 2000, USA).

\section{Biological material}

Swiss albino mice (Mus musculus; males, 6-week old), which had been inbred for several generations, were used for this study. The mice were obtained from the Department of Physiology in University of Ibadan, Oyo State, Nigeria. They were acclimatized in the animal house of the Department of Biology, The Federal University of Technology, Akure, with good ventilation and free of pathogens for 2 weeks and then subsequently throughout the period of the experiment. Food (Ladokun pelleted feed $\AA$ ) were supplied with good quality drinking water ad libitum.

\section{Hematological parameters}

Five concentrations of the sample $(50,25,10,5$, and $1 \%$; v/v, wastewater/distilled water) were used for this study, with distilled water as the negative control while cyclophosphamide $(20 \mathrm{mg} / \mathrm{kg}$ body weight) served as the positive control. Mice were intraperitoneally exposed to $0.3 \mathrm{ml}$ of each concentration of the wastewater for five consecutive days. After the 5 days of exposure, blood was collected from 5 animals per concentration into vials containing anticoagulant (EDTA). The rest 5 animals per concentration were allowed to stay for 21days post exposure before blood collection to study the residual effects. The jugular vein of the mice was punctured; the blood collected into EDTA tubes and analyzed using an Abacus Reflotron machine. Haematological parameters including white blood cells (WBC), red blood cells (RBC), heamaglobin (HGB), packed cell volume (PCV), lymphocytes (LYM), erythrocyte indices: Mean corpuscular heamaglobin count (MCHC), mean corpuscular heamablobin ( $\mathrm{MCH})$, mean corpuscular volume (MCV), leucocyte differential count: Monocytes, Neutrophils, Basophils and Eosinophils were analyzed.

\section{Statistical analysis}

All the statistical analyses were carried out using SPSS 22.0 statistical package. The comparison of the obtained data was done using one-way variance analysis. Least significant difference test was performed for multiple comparisons and $\mathrm{p}<0.05$ was used as the level of significance. 


\subsection{Results}

\section{Physico-chemical analysis}

The data obtained for the physico-chemical parameters of the wastewater of the cocoa industry are shown in Table 1. Phosphate, nitrate and chloride levels were low, while the levels of $\mathrm{Cu}, \mathrm{Fe}, \mathrm{Cr}, \mathrm{Pb}$, $\mathrm{Mn}, \mathrm{Cd}, \mathrm{As}, \mathrm{Ni}$, and $\mathrm{Zn}$ were higher than maximum allowable limit by regulatory organizations (NESREA, 2009; USEPA, 2009).

\section{Haematological parameters}

Tables 2-4 show the result of the haematological parameters recorded in mice exposed to wastewater from Cocoa Industry after 5 and 21 days. A significant $(\mathrm{p}<0.05)$ increase in the levels of neutrophils, monocytes, and eosinophils of the treated mice compared to the control group were observed after exposure to the wastewater for 5 days. The increment was significant and concentration dependent from $5 \%$ upward for neutrophils ( $68 \pm 0.41-76 \pm 0.80$ ), $10 \%$ upward for monocytes $(4.3 \pm 0.12-5.4 \pm 0.50)$ and $25 \%$ upward for eosinophils $(5.4 \pm 0.69-6.8 \pm 0.43)$ (Table 2). A similar trend was observed in MCV, WBC, and LYM with significant concentration-dependent increase

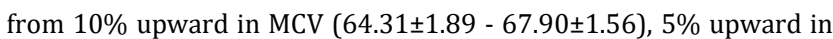
WBC $(6100 \pm 1.65-7903 \pm 1.11)$ and $10 \%$ upward in LYM $(44 \pm 1.06-$ $51 \pm 1.05$ ) after 5 days exposure to the wastewater (Tables 3-4). Basophils (1.5 $\pm 0.89-0.5 \pm 0.15)$, MCHC (14.34 $\pm 0.24-13.47 \pm 0.20)$, MCH (24.10 $\pm 0.72-19.06 \pm 0.62)$, and HGB (13.83 $\pm 0.51-13.0 \pm 0.09)$ reduced significantly $(\mathrm{p}<0.05)$ in the treated groups from $10 \%$ concentration and above, except for PCV $(43.5 \pm 0.55-38.0 \pm 0.04)$ and
RBC $(5.60 \pm 0.55-4.00 \pm 0.57)$ which were significant at $5 \%$ concentration upward after 5 days exposure compared to the control group (Table 4).

The result of the residual effects of the wastewater on the haematological parameters in exposed mice obtained 21 days after the last day of injection showed a similar trend of significant alterations of the haematological parameters with the results observed after 5 days exposure. The observed significant increase of the neutrophils, monocytes, eosinophils, WBC, LYM, and MCV levels persisted in the treated mice compared to the control group 21 days after the last exposure, while basophils, MCHC, MCH, HGB, PCV and RBC remained significantly reduced when compared with the negative control group. However, there was numerical reduction in the obtained values for neutrophils, monocytes, eosinophils, MCV, WBC, and LYM; and increase in the obtained values for basophils, MCH, MCHC, HGB, RBC and PCV in the 21 days group when compared with their respective concentrations in the 5 days group.

Table 1: Physical, chemical and heavy metals characteristics of wastewater from a cocoa industry

\begin{tabular}{|c|c|c|c|}
\hline Parameters & $\begin{array}{c}\text { Cocoa industry } \\
\text { wastewater }\end{array}$ & NESREA $^{a}$ & USEPA $^{b}$ \\
\hline Colour & Dark brown & - & - \\
\hline $\mathrm{pH}$ & 7 & $6-5-8.5$ & $6.5-8.5$ \\
\hline $\mathrm{EC}$ & 290 & - & - \\
\hline BOD & 122 & 30 & - \\
\hline COD & 203 & 250 & 410 \\
\hline TDS & 260 & 1200 & 500 \\
\hline Acidity & 9 & - & - \\
\hline Alkalinity & 72 & 20 & 20 \\
\hline Ammonia & 1.20 & 0.50 & 0.02 \\
\hline Chloride & 20 & 250 & 250 \\
\hline Sulphate & 1.69 & - & - \\
\hline Phosphate & 0.04 & 5.00 & - \\
\hline Nitrate & 0.12 & 10.00 & 10.00 \\
\hline Cadmium & 0.14 & 0.005 & 0.005 \\
\hline Lead & 2.9 & 0.01 & - \\
\hline Copper & 1.32 & 0.05 & 1.0 \\
\hline Chromium & 1.00 & 0.1 & 0.1 \\
\hline Zinc & 0.82 & 1.5 & 5.0 \\
\hline Iron & 1.40 & 0.03 & 0.30 \\
\hline Manganese & 0.35 & 0.1 & 0.05 \\
\hline Arsenic & 0.82 & - & - \\
\hline Nickel & 0.43 & 0.01 & - \\
\hline
\end{tabular}

EC - Electrical conductivity, BOD - Biochemical oxygen demand, COD - Chemical oxygen demand, TDS - Total dissolved solid, NESREA - National Environmental Standards and Regulation Enforcement Agency (2009), USEPA ${ }^{\mathrm{b}}$ - United States Environmental Protection Agency (2009). Units of the parameters are in $\mathrm{mg} / \mathrm{L}$ except for $\mathrm{pH}$ which has no unit and $\mathrm{EC}$ in $\mu \mathrm{Scm}^{-1}$. 
Table 2: Immediate and residual leucocytes differential counts of mice treated with different concentrations of wastewater from a cocoa Industry.

\begin{tabular}{ccccccccc}
\hline & \multicolumn{3}{c}{5 days } & & \multicolumn{2}{c}{21 days } \\
\hline Conc (\%) & $\begin{array}{c}\text { Neutrophils } \\
(\%)\end{array}$ & $\begin{array}{c}\text { Monocytes } \\
(\%)\end{array}$ & $\begin{array}{c}\text { Basophils } \\
(\%)\end{array}$ & $\begin{array}{c}\text { Eosinophils } \\
(\%)\end{array}$ & $\begin{array}{c}\text { Neutrophils } \\
(\%)\end{array}$ & $\begin{array}{c}\text { Monocytes } \\
(\%)\end{array}$ & $\begin{array}{c}\text { Basophils } \\
(\%)\end{array}$ & $\begin{array}{c}\text { Eosinophils } \\
(\%)\end{array}$ \\
\hline DW & $58 \pm 0.59$ & $2.8 \pm 0.90$ & $2.0 \pm 1.0$ & $3.2 \pm 0.89$ & $58 \pm 0.59$ & $2.8 \pm 0.90$ & $2.0 \pm 1.0$ & $3.2 \pm 0.89$ \\
1 & $60 \pm 1.01$ & $2.9 \pm 0.21$ & $2.1 \pm 0.21$ & $3.3 \pm 0.40$ & $60 \pm 0.01$ & $2.8 \pm 0.10$ & $2.0 \pm 0.05$ & $3.2 \pm 0.04$ \\
5 & $68 \pm 0.41^{*}$ & $3.9 \pm 0.23$ & $1.8 \pm 0.76$ & $3.9 \pm 0.30$ & $65 \pm 0.01^{*}$ & $3.4 \pm 0.02$ & $1.9 \pm 0.06$ & $3.7 \pm 0.05$ \\
10 & $69 \pm 0.72^{*}$ & $4.3 \pm 0.12^{*}$ & $1.5 \pm 0.89^{*}$ & $4.6 \pm 0.15$ & $66 \pm 0.02^{*}$ & $4.1 \pm 0.02^{*}$ & $1.7 \pm 0.02^{*}$ & $4.2 \pm 0.01$ \\
25 & $72 \pm 0.01^{*}$ & $5.0 \pm 0.60^{*}$ & $1.1 \pm 0.12^{*}$ & $5.4 \pm 0.69^{*}$ & $70 \pm 0.05^{*}$ & $4.8 \pm 0.03^{*}$ & $1.4 \pm 0.20^{*}$ & $4.9 \pm 0.01^{*}$ \\
50 & $76 \pm 0.80^{*}$ & $5.4 \pm 0.50^{*}$ & $0.5 \pm 0.15^{*}$ & $6.8 \pm 0.43^{*}$ & $73 \pm 0.02^{*}$ & $5.1 \pm 0.05^{*}$ & $1.0 \pm 0.02^{*}$ & $5.7 \pm 0.11^{*}$ \\
CYC & $77 \pm 0.37^{*}$ & $5.5 \pm 0.70^{*}$ & $0.2 \pm 0.90^{*}$ & $7.3 \pm 0.48^{*}$ & $77 \pm 0.37^{*}$ & $5.5 \pm 0.70^{*}$ & $0.2 \pm 0.90^{*}$ & $7.3 \pm 0.48^{*}$ \\
\hline
\end{tabular}

DW: Distilled water; CYC: Cyclophosphamide. *Significant at $\mathrm{p}<0.05$.

Table 3: Immediate and residual erythrocyte indices of mice treated with different concentrations of wastewater from a cocoa Industry.

\begin{tabular}{|c|c|c|c|c|c|c|}
\hline \multirow[b]{2}{*}{ Conc (\%) } & \multicolumn{3}{|c|}{5 days } & \multicolumn{3}{|c|}{21 days } \\
\hline & $\mathrm{MCH}(\mathrm{pg})$ & MCHC (\%) & $\mathrm{MCV}(\mathrm{fl})$ & MCH (pg) & MCHC (\%) & $\mathrm{MCV}(\mathrm{fl})$ \\
\hline DW & $28.2 \pm 0.21$ & $16.83 \pm 0.65$ & $60.04 \pm 1.81$ & $28.2 \pm 0.21$ & $16.83 \pm 0.65$ & $60.04 \pm 1.81$ \\
\hline 1 & $27.87 \pm 0.80$ & $16.22 \pm 0.01$ & $60.40 \pm 1.01$ & $28.00 \pm 0.01$ & $16.61 \pm 0.10$ & $60.40 \pm 0.05$ \\
\hline 5 & $26.69 \pm 0.63$ & $15.29 \pm 0.50$ & $62.04 \pm 0.35$ & $25.02 \pm 0.31^{*}$ & $16.01 \pm 0.01$ & $61.47 \pm 0.50$ \\
\hline 10 & $24.10 \pm 0.72^{*}$ & $14.34 \pm 0.24^{*}$ & $64.31 \pm 1.89^{*}$ & $24.00 \pm 0.10^{*}$ & $15.10 \pm 0.11^{*}$ & $63.06 \pm 0.03^{*}$ \\
\hline 25 & $21.31 \pm 0.47^{*}$ & $14.00 \pm 0.19^{*}$ & $67.21 \pm 1.11^{*}$ & $21.00 \pm 0.21^{*}$ & $14.00 \pm 0.01^{*}$ & $66.87 \pm 0.01^{*}$ \\
\hline 50 & $19.06 \pm 0.62^{*}$ & $13.47 \pm 0.20^{*}$ & $67.90 \pm 1.56^{*}$ & $20.81 \pm 0.55^{*}$ & $13.00 \pm 0.08^{*}$ & $67.21 \pm 0.04^{*}$ \\
\hline CYC & $19.13 \pm 0.21 *$ & $13.35 \pm 0.88^{*}$ & $67.67 \pm 1.66^{*}$ & $19.13 \pm 0.21^{*}$ & $13.35 \pm 0.88^{*}$ & $67.67 \pm 1.66^{*}$ \\
\hline
\end{tabular}

DW: Distilled water; CYC: Cyclophosphamide; MCV: Mean corpuscular volume; MCHC: Mean corpuscular haemoglobin concentration; MCH: Mean corpuscular haemoglobin; ${ }^{*}$ Significant at $\mathrm{p}<0.05$.

Table 4: Immediate and residual haematological parameters of mice treated with different concentrations of wastewater from a cocoa Industry.

\begin{tabular}{|c|c|c|c|c|c|c|c|c|c|c|}
\hline & & \multicolumn{4}{|c|}{5 days } & & \multicolumn{4}{|c|}{21 days } \\
\hline $\begin{array}{c}\text { Con } \\
\text { c } \\
(\%)\end{array}$ & $\begin{array}{c}\text { WBC } \\
\left(\mathrm{mm}^{3}\right)\end{array}$ & $\begin{array}{l}\text { LYM } \\
(\%)\end{array}$ & $\mathrm{HGB}(\mathrm{g} / \mathrm{dL})$ & PCV (\%) & $\begin{array}{c}\mathrm{RBC} \\
\left(\mathrm{x} 10^{6} / \mathrm{mm}^{3}\right)\end{array}$ & $\begin{array}{c}\mathrm{WBC} \\
\left(\mathrm{mm}^{3}\right)\end{array}$ & $\begin{array}{l}\text { LYM } \\
(\%)\end{array}$ & HGB (g/dL) & PCV (\%) & $\begin{array}{c}\mathrm{RBC} \\
\left(\mathrm{x} 10^{6} / \mathrm{mm}^{3}\right)\end{array}$ \\
\hline DW & $5230 \pm 1.71$ & $34 \pm 1.27$ & $15.2 \pm 1.00$ & $48.5 \pm 0.28$ & $7.21 \pm 0.28$ & $5230 \pm 1.71$ & $34 \pm 1.27$ & $15.2 \pm 1.00$ & $48.5 \pm 0.28$ & $7.21 \pm 0.28$ \\
\hline 1 & $5280 \pm 1.11$ & $34 \pm 1.35$ & $15.0 \pm 0.03$ & $47.2 \pm 1.01$ & $7.01 \pm 0.30$ & $5250 \pm 0.55$ & $35 \pm 0.22$ & $15.2 \pm 0.41$ & $47.6 \pm 0.30$ & $7.10 \pm 0.11$ \\
\hline 5 & $\begin{array}{c}6100 \pm 1.65 \\
*\end{array}$ & $37 \pm 1.17$ & $14.0 \pm 0.17$ & $\begin{array}{c}43.5 \pm 0.55 \\
*\end{array}$ & $\begin{array}{c}5.60 \pm 0.55 \\
*\end{array}$ & $\begin{array}{c}5900 \pm 0.10 \\
*\end{array}$ & $36 \pm 0.52$ & $14.5 \pm 0.44$ & $\begin{array}{c}44.0 \pm 0.10 \\
*\end{array}$ & $6.00 \pm 0.01$ \\
\hline 10 & $\begin{array}{c}6900 \pm 1.44 \\
*\end{array}$ & $\begin{array}{c}44 \pm 1.06 \\
*\end{array}$ & $\begin{array}{c}13.83 \pm 0.51 \\
*\end{array}$ & $\begin{array}{c}40.3 \pm 0.47 \\
*\end{array}$ & $\begin{array}{c}5.30 \pm 0.45 \\
*\end{array}$ & $\begin{array}{c}6400 \pm 0.21 \\
*\end{array}$ & $\begin{array}{c}42 \pm 0.10 \\
*\end{array}$ & $\begin{array}{c}13.98 \pm 0.11 \\
*\end{array}$ & $\begin{array}{c}42.0 \pm 0.05 \\
*\end{array}$ & $\begin{array}{c}5.80 \pm 0.50 \\
*\end{array}$ \\
\hline 25 & $\begin{array}{c}7251 \pm 1.00 \\
*\end{array}$ & $\begin{array}{c}48 \pm 1.39 \\
*\end{array}$ & $\begin{array}{c}13.10 \pm 0.22 \\
*\end{array}$ & $\begin{array}{c}38.6 \pm 1.10 \\
*\end{array}$ & $\begin{array}{c}4.45 \pm 0.46 \\
*\end{array}$ & $\begin{array}{c}7062 \pm 0.21 \\
*\end{array}$ & $\begin{array}{c}46 \pm 0.23 \\
*\end{array}$ & $\begin{array}{c}13.41 \pm 0.90 \\
*\end{array}$ & $\begin{array}{c}39.5 \pm 0.10 \\
*\end{array}$ & $\begin{array}{c}5.40 \pm 0.22 \\
*\end{array}$ \\
\hline 50 & $\begin{array}{c}7903 \pm 1.11 \\
*\end{array}$ & $\begin{array}{c}51 \pm 1.05 \\
*\end{array}$ & $13.0 \pm 0.09 *$ & $\begin{array}{c}38.0 \pm 0.04 \\
*\end{array}$ & $\begin{array}{c}4.00 \pm 0.57 \\
*\end{array}$ & $\begin{array}{c}7511 \pm 0.10 \\
*\end{array}$ & $\begin{array}{c}49 \pm 0.05 \\
*\end{array}$ & $13.0 \pm 0.21 *$ & $\begin{array}{c}38.0 \pm 0.10 \\
*\end{array}$ & $\begin{array}{c}4.05 \pm 0.09 \\
*\end{array}$ \\
\hline CYC & $\begin{array}{c}8100 \pm 1.01 \\
*\end{array}$ & $\begin{array}{c}53 \pm 1.11 \\
*\end{array}$ & $12.2 \pm 0.33^{*}$ & $\begin{array}{c}30.0 \pm 0.02 \\
*\end{array}$ & $6.00 \pm 0.90$ & $\begin{array}{c}8100 \pm 1.01 \\
*\end{array}$ & $\begin{array}{c}53 \pm 1.11 \\
*\end{array}$ & $12.2 \pm 0.33^{*}$ & $\begin{array}{c}30.0 \pm 0.02 \\
*\end{array}$ & $6.00 \pm 0.90$ \\
\hline
\end{tabular}

DW: Distilled water; CYC: Cyclophosphamide; WBC: White blood cell; LYM: Lymphocytes; HGB: Haemoglobin; RBC: Red blood cell; ${ }^{*}$ Significant at $p<0.05$. 


\subsection{Discussion}

This study was carried out to assess the immediate and residual haematological toxicity of wastewater from cocoa industry in mice. In animals, blood can be a physiological and pathological indicator of the health status (Jorum et al., 2016), hence, haematological parameters are recognized as good indicators of the physiological state of the body and therefore can be used for the diagnoses of the functional and structural status of animals exposed to different pollutants and contaminants (Adhikari et al., 2004; Seriani et al., 2010). The results obtained in the present study indicate significant alterations in hematological profile of the test animals treated with cocoa industry wastewater. The data of the present study showed a significant decrease in RBC indices in exposed mice. RBC indices are reflections of the level of haemoglobin content (MCHC and MCH) and the size (MCV) of the RBC, which can be used for diagnosing the cause of anaemia. These indices can help to identify the type of morphological anaemia (microcytic, macrocytic or normocytic anemia) that is experienced by the animal. The results further showed a significant increase in MCV and decrease in MCHC and MCH in mice exposed to cocoa industry wastewater. The levels of $\mathrm{MCHC}$ and $\mathrm{MCH}$ suggest that mice exposed to the wastewater might be suffering from macrocytic anaemia. These recorded alterations in the haematological indices might be a form of defense mechanism against the toxicity of heavy metals especially $\mathrm{Pb}$ and $\mathrm{Cr}$, which were found in high concentrations in the tested wastewater. Increase in MCV and WBC count in this study further supports the possibility of macrocytic anaemia in exposed mice (Afaq, 2009). Since MCV can be a good indicator of the size of the RBC and also reflects a normal or an abnormal cell division during the process of erythropoiesis, therefore, increased level of MCV in this study could be due to erythrocytes swelling caused by osmotic stress, macrocytic anaemia or hypoxic condition in mice exposed to the wastewater (Sinha et al., 2000). The alterations to the RBC and its indices could also be attributed to the toxic effect of the wastewater on the bone marrow of the exposed mice leading to the damage of its haemopoietic cells. Lee et al. (1999) reported that wastewater's toxic constituents can cause metabolic disorder in the RBC leading to decrease in their heamaglobin carrying capacity. As a result of the toxicity of the wastewater, the bone marrow might not be capable of producing haemoglobin at the rate required, hence, causing reduced level of MCHC.

The PCV level is an indication of the blood's oxygen carrying capacity and the level of stress on animal health (Larson et al., 1985). The low PCV observed in this study further indicated anemia. The reduction in mean of PCV values obtained in the present study might be caused by decrease in the number of circulating RBC and also shrinkage of the cell (Ahmad et al., 1995). The report of Kurde and Singh (1995) also recorded a decreased PCV in male albino mice exposed to wastewater. The results of this study further showed that HGB decreased significantly in the treated mice. Haemoglobin functions as the carrier of oxygen to tissues. Low concentration of HGB limits the blood's oxygen carrying capacity, resulting in different clinical signs including a general body weakness. Generally, insufficient supply of iron during the different stages of erythrocyte's maturation leads to decrease in the synthesis of haemoglobin. When haemoglobin breaks down, iron is released and subsequently transported by transferring to either the bone marrow to produce new red blood cells or stored in the liver as ferritin. This stored ferritin usualy supplies the iron needed for the synthesis of new haemoglobin. Hence, it might be that the metal content of the cocoa industry wastewater have displaced the iron which is required for haemoglobin synthesis thereby resulting in the reduction of the haemoglobin content of the exposed mice. Similar to the present report are the reports of Sharma and Goyal (2005) and Devi and Singh (1988) who reported significant reduction in haemoglobin level in animals exposed to effluent poisoning.

Results of the present study also showed an increase in WBC and LYM levels; and leucocytes differential counts (neutrophils, monocytes and eosinophils) in the exposed mice. Tort (2011) points out that some immune cells may increase as a precautionary measure or response to stressful stimuli. The major role of WBC is to provide both non-specific and specific immunity, and its level increases when infection occurs. WBC provides immunity against foreign attack by recognizing the pathogen as an invader before destroying it. Therefore, increase in the level of WBC is indicative of leukocytosis which might be due to benign conditions such as hemolytic anaemia, stress, tissue necrosis, inflammation, and infections (Abramson and Melton, 2000; Schafer, 2004). Indeed, Lunden and Bylund (2002) have reported that when there is any foreign stress in the biological system, the spleen responds by producing new WBCs. The increased WBC count in this study might therefore be an indication of increased production of antibodies in the exposed mice. Also, this rise in total WBC and LYM count may be due to hyper stimulation of hematopoietic regulatory elements which regulates proliferation by the wastewater (Yakubu and Afolayan, 2009). It is possible that the Cocoa industry wastewater made the exposed mice more susceptible to opportunistic pathogen invasion which has led to increased level of the WBC.

The residual effect of the wastewater on the hematological parameters of the exposed mice showed that the constituents of the wastewater persisted in the system of the mice 21 days after exposure has stopped. 
The alterations to the hematological parameters observed after 5 days exposure persisted and were still statistically significant after the recovery period of 21 days. Indeed, reports (Jadhav et al., 2007, Adham et al., 2011) have shown that heavy metals present in the wastewater can persist in biological system and therefore persistently induce systemic toxicity in exposed organisms.

The data obtained for the physico-chemical characteristics of the Cocoa industry wastewater revealed the presence of some known toxicants. Different concentrations of $\mathrm{Cr}, \mathrm{Cd}, \mathrm{Pb}, \mathrm{Zn}, \mathrm{Cu}, \mathrm{Al}$. $\mathrm{Mn}, \mathrm{Ag}$, and $\mathrm{Ni}$ were recorded in the Cocoa industry wastewater. The observed immediate and residual hematotoxic effect of the cocoa industry wastewater is believed to be as a result of these metals. Lead is known for causing oxidative stress in RBC and resulting into anemia (Mohammadhosien et al., 2003). The decrease in HGB is probably due to toxicity of heavy metals such as $\mathrm{Pb}$ and $\mathrm{Zn}$ present in the cocoa industry wastewater. Lead interferes with biosynthesis of haem by adversely affecting the responsible enzyme system as well as ribosomal degeneration (Jadhav et al., 2007, Adham et al., 2011). It has been documented that heavy metals can alter HGB properties by decreasing their capacity to bind oxygen rendering the erythrocytes more permeable and fragile causing cell deformation, swelling, and damage (Ogundiran et al., 2007; Vinodhini and Narayanan 2009). Haematotoxic effect of the Cocoa industry wastewater reported in this study might also be due to the synergistic reaction of the different metal constituents which might induce higher toxicity than the individual metal. Besides causing haematotoxicity, previous studies have shown other damaging effects of some of the identified heavy metals. Ni has been reported to cause highly selective heterochromatin damage (Costa et al., 1994). Reports of researches using experimental animals showed the carcinogenicity of Cd (Elinder and Jarup, 1996) and Ni (Haugen et al., 1994). Hexavalent $\mathrm{Cr}$ has been documented to induce single-strand breaks, micronuclei and chromosomal aberrations in mammalian cells (Wise et al., 2002), and gene mutation in bacteria (DeFlora et al., 1990). It has also been reported that $\mathrm{Cd}, \mathrm{Cu}$ and Fe gave rise to reactive oxygen species in eukaryotic systems (Ghio et al., 2002; Radetski et al., 2004). Trivalent Fe was also reported as having been responsible for the high level of micronuclei in newt larvae (Godet et al., 1996). The exposure of mice to $\mathrm{Zn}$ results in both single-strand breaks in DNA, as measured by the comet assay (Banu et al., 2001), as well as chromosomal aberrations (Gupta et al., 1991). The metal constituents analyzed in this study is only a tiny fraction of the chemicals that might be present in the cocoa industry wastewater. This is because a wastewater is a complex mixture of inorganic and organic chemicals, which might contain many unidentified toxicants (nonconventional pollutants), all of which might be of great public health risk. Akinnusotu and Aranwade (2016), Alabi et al. (2017), and Alabi and Sorungbe (2019) reported similar observations of high concentration of heavy metals in wastewater obtained from cocoa processing factories. The metal concentrations were shown to be higher than maximum allowable by standard regulatory organizations.

In conclusion, determination of the level of haematological parameters was shown in this study as an important means of determining the health status of experimental animals exposed to toxicants (Soud, 2004; Alghamdi and El-Ghazaly, 2012). These measurements can be used for the diagnosis of diseases such as leukemia, anemia, and for the detection of inflammation (Fatayer, 2006; Alghamdi and ElGhazaly, 2012). Blood parameters like numbers of erythrocytes and white blood cells, hematocrit, and haemoglobin are good indicators of toxicity with potential broad application in occupational and environmental monitoring (Sancho et al., 2000; Barcellos et al., 2003). The present report revealed that wastewater from cocoa industry contained toxic metals capable of inducing immediate and residual haematological alterations in exposed mice. There is therefore need for monitoring of the disposal of this type of waste to safeguard the health of the environment and the general populace.

\section{Declaration of Conflict of Interests}

No conflict of interests.

\section{Authors' Contributions \\ Conception: [0OA] \\ Design: [0OA] \\ Execution: [0OA] \\ Interpretation: [0OA] \\ Writing the paper: $[00 \mathrm{~A}]$}

\section{References}

Abramson, N., Melton, B. 2000. Leukocytosis: Basics of clinical assessment. Am. Fam. Phys. 62: 2053-2060.

Adham, K.G., Al-Eisa, N.A., Farhood, M.H. 2011. Impact of heavy metal pollution on the hemogram and serum biochemistry of the libyan jird, Meriones libycus. Chemosphere. 84(10): 1408-1415.

Adhikari, S., Sarkar, B., Chatterjee, A., Mahapatra, C.T., Ayyappan, S. 2004. Effects of cypermethrin and carbofuran on certain hematological parameters and prediction of their recovery in a freshwater teleost; Labeo rohita (Hamilton). Ecotoxicol. Environ. Saf. 58: 220-226.

Afaq, S. 2009. Toxicological effects of Leather dyes on total Leucocyte count of fresh water teleost, Cirrhunus mrigala (Ham). Biol. Med. 1(2): 134-138.

Ahmad, F., Ali, S.S., Shakoori, A.R. 1995. Sublethal effects of danitor (fenpropathrin), a synthetic pyrethroid on fresh water Chinese grass carp, Ctenopharyngodon idella. Folia Biol. 43: 151-159. 
Akinnusotu, A., Arawande, J.0. 2016. Qualities of Effluents from three Cocoa Processing Factories in Ondo State. Inter. J. Environ. Bioengineer. 11(1): 24-35.

Alabi, O.A., Sorungbe, A.A. 2019. DNA damage induced by wastewater from cocoa industry in two prokaryotic systems, Inter. J. Environ. Studies. 79: 370-378.

Alabi, O.A., Esan, E.B., Olorunfunmi, J.T., Oludare, O.E. 2017, Assessment of environmental contamination by wastewater from a cocoa processing industry using genetic and reproductive biomarkers. J. Toxicol. Risk Assess. 3: 008.

Alghamdi, M.S., El-Ghazaly, N.A. 2012. Effects of exposure to electromagnetic field on some hematological parameters in mice. Open J. Med. Chem. 2: 30-42.

APHA, 2005. Standard Methods for the Examination of Water and Wastewater, American Public Health Association, Washington, DC, USA, 21th edition.

Bakare, A.A., Alabi, O.A. Gbadebo, A.M. Ogunsuyi, O.I., Alimba, C.G. 2013. In vivo cytogenotoxicity and oxidative stress induced by electronic waste leachate and contaminated well water. Challenges. 4: 169-187.

Banu, B.S., Devi, K.D., Maliboob, M., Jamil, K. 2001. In vivo genotoxic effect of zinc sulfate in mouse peripheral blood leukocytes using comet assay. Drug Chem. Toxicol. 24: 63-73.

Barcellos, L.J.G., Kreutz, L.C., Rodrigues, L.B., Fioreze, I., Quevedo, R.M., Cericato, L., Conrad, J., Soso, A.B., Fagundes, M., Lacerda, L.A., Terra, S. 2003. Haematological and biochemical characteristics of male jundiá (Rhamdia Quelen, Quoy \& GaimaRDT, Pimelodidae): changes after acute stress. Aquacul. Res. 34: 1465-1469

Costa, M., Salnikow, K., Consentino, S., Klein, C.B., Huang, X., Zhaung, Z. 1994. Molecular mechanism of nickel carcinogenesis. Environ. Health Perspect. 102: 127-130.

DeFlora, S., Begnasco, M., Serra, D., Zanacchi, P. 1990. Genotoxicity of chromium compounds. Mutat. Res. 238: 99-178.

Devi, S., Singh, H. 1988. Axo-carmine induced haematological and biochemical change in albino Rat. J. Environ. Biol. 9(1): 21-25.

Elinder, C.G., Jarup, L. 1996. Cadmuim exposure and health risks: Recent findings. Ambio. 25: 370-373.

Fatayer, A.R. 2006. Hematology (Theoretical and practical) culture library house for publication and distribution. J. Environ. Stud. 2: 223229.

Ghio, A.J., Silbajoris, R., Carson, J.L., Samet, J.M. 2002. Biologic effects of oil fly ash. Environ. Health Perspect. 110: 89-94.

Godet, F., Babut, M., Burnal, D., Verler, A.M., Vasscur, P. 1996. The genotoxicity of iron and chromium in electroplating effluents. Mutat. Res. 370: 19-28.

Gupta, T., Talukder, G., Sharma, A. 1991. Cytotoxicity of zinc chloride in mice in vivo Biol. Trace Elem. Res. 30: 95-101.
Haugen, A., Maehle, L., Mollerup, S., Rivedal, E., Ryberg, D. 1994. Nickel induced alteration in human renal epithelial cells. Environ. Health Perspect. 102: 117-118.

Hymavathi, V., Rao, L.M. 2000. Effect of sublethal concentrations of lead on the haematology and biochemical constituents of Channa punctatus. Bull. Pure Applied Sci. 19: 1-5.

Jadhav, S.H., Sarkar, S.N., Ram, G.C., Tripathi, H.C. 2007. Immunosuppressive effect of subchronic exposure to a mixture of eight heavy metals, found as groundwater contaminants in different areas of India, through drinking water in male rats. Arc. Environ. Contaminat. Toxicol. 53(3): 450-458.

Jorum, O.H., Piero, N.M., Machocho, A.K. 2016. Haematological Effects of Dichloromethane-Methanolic Leaf Extracts of Carissa edulis (Forssk.) Vahl in Normal Rat Models. J. Hematol. Thromboembolic Dis. 5: 2 .

Kurde, S., Singh, R. 1995. Effects of two samples of textile effluents and dyes on total erythrocyte counts and related parameters of Wister rats. Proc. Acad. Environ. Biol. 4: 177-181.

Larson, A., Haux, C., Sjobeck, M. 1985. Fish physiology and metal pollution: results and experiences from laboratory and field studies. Ecotoxicol. Environ. Saf. 9: 250-281.

Lee, G.R., Forester, J., Lukens, J., Paraskevas, F., Greer, J.P., Rodgers, G.M. 1999. Laboratory Haematology: Examination of the blood and bone marrow. In: Wintrobe's Clinical Haematology, 10th ed. Williams and Wilkins, USA. Pp 2763.

Lunden, T., Bylund, G. 2002. Effect of sulphadiazine and trimethoprim on the immune response of rainbow trout (Oncorhynchus mykiss). Vet. Immunol. Immunopath. 85(1-2): 99-108.

Mohammadhosein, N.M., Heidari, Z., Sagheb, H.M., Barbarestani, M. 2003. Effects of Chronic Lead Acetate Intoxication On Blood Indices Of Male Adult Rat. Daru. 11(4): 147-151.

National Environmental Standards and Regulation Enforcement Agency (NESREA); (Federal Republic of Nigeria Official Gazette); National Environmental (Sanitation and Waste Control). Federal Government of Nigeria Printer, Abuja, Nigeria, (2009); FGP 112/102009/L000 (OL54). No.60 (96); pp. 1057-1102.

Ogundiran, M.A., Fawole, O.O., Adewoye, S.O. 2007. Effects of Soap and detergent effluents on the haematological indices and biochemical profiles of Clarias gariepinus. Sci. Focus. 12(1): 84-88.

Radetski, C.M., Ferrari, B., Cotelle, S., Masfaraud, J.F., Ferard, J.F. 2004. Evaluation of the genotoxic, mutagenic and oxidant stress potentials of municipal solid waste incinerator bottom ash leachates. Sci. Total Environ. 333: 209-216.

Rahman, M.F., Siddiqui, M.K. 2006. Hematological and clinical chemistry changes induced by subchronic dosing of a novel phosphorothionate (RPR-V) in Wistar male and female rats. Drug Chem. Toxicol. 29: 95-110.

Sancho, E., Cerón, J.J., Ferrando, M.D. 2000. Cholinesterase activity and hematological parameters as biomarkers of sublethal molinate exposure in Anguilla anguilla. Ecotoxicol. Environ. Saf. 46: 81-86. 
Schafer, A.I. 2004. Thrombocytosis. N. Engl. J. Med. 350: 1211-1219.

Seriani, R., Moreira, L.B., Abessa, D.M.S., Maranho, L.A., Abujamara, L.D., Carvalho, N.S.B., Kirschbaum, A.A., Ranzani-Paiva, M.J.T. 2009. Haematological analysis in Micropogonias furnieri from two estuaries at Baixada Santista, São Paulo, Brazil. Braz. J. Ocean., 58 (special issue IV SOB): 87-92.

Sharma, A., Goyal, R.P. 2005. Haemotoxic effects of chocolate brown, a commonly used blend of permitted food colour on swis albino mice. Asian. J. Exp. Sci. 19(2): 93-103.

Sinha, A.K., Sinha, M.K., Adhikari, S. 2000. Effect of the copper toxicity on haematological profile of Indian major corp, Lobeo rohita, Hand book Industry Environ. Pollut., 166-172.

Soud, R. 2004. Human and the environment (education study of the environment) Dar Al-Hamed for publication and distribution. J. Environ. Stud. 1: 23-31.

Tort, L. 2011. Stress and immune modulation in fish. Dev. Comp. Immunol. 35(12): 1366-1375.

United State Environmental Protection Agency (USEPA) 2009: Drinking water contamination Washington Dc. USEPA. http:// water.epa.gov/drink/contaminants/index.cfm\#.List
Vinodhini, R., Narayanan, M. 2009. The Impact of toxic heavy metals on the hematological parameters in common Carp (Cyprinus carpio L.). Iranian J. Environ. Health Sci. Engineer. 6(1): 23-28.

Wise, J.P., Wise, S.S., Little, J.E. 2002. The cytotoxicity and genotoxicity of particulate and soluble hexavalent chromium in human lung cells. Mutat. Res. 517: 221-229.

Yakubu, M.T., Afolayan, A.J. 2009. Effects of aqueous extracts of Bulbine natalensis Baker stem on hematological and serum lipid profile of male wistar rats. Indian J. Exp. Biol. 47: 283-288.

Yakubu, M.T., Akanji, M.A., Oladiji, A.T. 2007. Hematological evaluation in male albino rats following chronic administration of aqueous extract of Fadogia agrestis stem. Pharmacogn. Mag. 3: 34-38. 